STRATEGIES FOR THE SOCIAL CONSTRUCTION OF TECHNOLOGY THE CASE OF SPACE FLIGHT IN THE FEDERAL REPUBLIC OF GERMANY

\section{Johannes Weyer}

When the European Research Ministers on November 9, 1987 determined on the "European Long Term Space Plan 1987 - 2000" 1 , they opted for a big technology only comparable to nuclear technology or large scale military technologies such as e.g. SDI. The new dimensions European space flight now is aiming at, can be characterized by different aspects:

i) The financial resources required to build up the European space systems are immense. Official figures of the German Research Ministry (BMFT) in 1987 accounted for 14 billion DM, which is equivalent to about two fast breeders, but it could be demonstrated by recalculating the ESA figures that much more money would be required. My prediction of 1987 that at least 8 billion DM more would be required 2 and that this would raise unsolvable problems for the research budget in the 1990s now has been confirmed by German officials ${ }^{3}$, which arouses suspicions that the real problems might be even worse.

ii) The technical systems of the ESA programme focus on manned space flight, which also indicates a new qualitiy in European space politics. The space station modules, named COLUMBUS, the mini shuttle HERMES, and the new rocket ARIANE V, mainly required to launch HERMES, all indicate that a large amount of resources within the long term programme is directed towards manned space flight. Other projects such as planetary missions or scientific exploration of the earth will, according to official ESA plannings, slowly be reduced from $68.5 \%$ (1987) to $28.8 \%$ (1993) and then to $26.4 \%$ (2000) of the total ESA budget ${ }^{4}$, and a continuing cost explosion of manned systems might even accelerate this trend. Projects such as earth observation or astronomic missions are to be shifted to manned systems, but the community heavily criticizes this. The arguments are well-known: manned space flight is a hinderance not a promotion for research. 5

iii) According to the strategies pursued by the German space lobby (Western) Europe should obtain a leading rule in this new struggle for superiority in the world. In these concepts space flight is regarded as a symbolic instrument for the creation and prevailance of these new politics. ${ }^{6}$ In my view the political usefulness of space flight is the only explanation for the emphasis given to manned systems. German astronauts in space are of only marginal use for the progress of science or economics, but the specific visibility of manned missions and the symbolic effect of being the first anywhere are of great use for politics, especially in the age of international hightech competition. 7

iv) Another new dimension of the space programme is the social implications of this enterprise, which again demonstrate its deeply political character. In 1989, two years after the ESA decision, lenghty negotiations about the foundation of a German space agency (DARA) and a German industrial-military-aerospace complex (Daimler-MBB) were completed and the two new institutions were finally established. In both cases a dissolution of traditional organizational arrangements which had been constitutive for German space politics and a construction of totally new social relations took place. The delegation of the space programme to a private agency may be regarded as an important turning-point in West Germany's research politics.

The purpose of this paper is to explain the social restructuring triggered by a technology programme and to ask why technology can play this intermediate role in social games. The hypothesis of this paper is as follows: In the case of space flight (and maybe in some other cases) technology has no value of its own, but is regarded by the co-players as a means of restructuring the social arena in a way that serves one's own interests. The configuration of the technology and its concrete use are of less importance compared with its function of establishing social networks between different social groups.

The underlying assumption of this argument that manned space flight is a useless technology will be quite briefly discussed before outlining the sociologic model .

\section{The endless disaster of the European space programme}

In the years 1984 to 1987 proponents of the new ESA programme created a picture of manned space flight to be the key to Europe's future. Without the new space systems Europe would fall back in the technological and economic race and soon be at the level of an underdeveloped country. ${ }^{8}$ Research and development activities only possible under microgravity conditions 9 were judged as the forefront of scientific progress and as the key to technological and economic leadership. These arguments have frequently been rejected and refuted by most of its addressees, i.e. the scientific community and the non-aerospace industry. 10 Nevertheless they helped to legitimize the space projects in public debates. Only shortly after the ESA decision of 1987 , however, it became obvious that even the space systems which constitute the technical base of all the premises will not work. The reasons are partly technical, partly political. HERMES, The European mini-shuttle, had to be modified according to new safety standards developed after the CHALLENGER crash - information possibly held back until November 1987 in order not to disturb the ESA decision. The final outcome of all HERMES modifications is likely to lead to the result that HERMES will never fly or, if it can fly, it will not be able to carry a payload. After all HERMES is a useless project, a very expensive re-invention of the shuttle, which has gradually been redefined as a technology project indispensable for the development of the next generation of shuttles on the one hand and - besides - new hypersonic combat aircraft on the other. ${ }^{11}$ The history of the space station since 1987 also challenges the assertion that Europe's future will depend on manned space flight. Only some weeks after the signing of the Memoran- 
dum of Understanding between NASA and ESA on September 29, 1988 concerning the European COLUMBUS module (which is to become part of the U.S. space station) it became public that NASA, forced by budgetary pressure, is going to withdraw from the station project step by step. The configuration of the space station has been reduced to a minimum of the scale which the European had been baited with, the launch of the station has been delayed several times. 12 It is questionable whether manned space systems to be launched in the late 1990s using technologies of the $70 \mathrm{~s}$ and $80 \mathrm{~s}^{13}$ may be called high tech in an age when the innovation cycle in technology intensive industries has been reduced to only a few years. Even the Soviet Union is now calling into doubt their very cost-expensive space programme, although the Soviet approach had been much more conservative and incremental than the U.S.-European plans.

Considering the disastrous situation of European space projects it is hardly surprising that the arguments propagated by the critics of manned space flight in 1986/87 are now common-sense even in parts of the German governmental parties. ${ }^{14}$ Now it can be asked why the consequences of the ESA decision, which had been predicted already in 1987, were not taken into consideration when the decision was made. Was it foolish politicans who launched a programme of the scale of manned space flight without conducting a serious technology assessment beforehand? Some aspects of the problem may be covered by that argument, but as a sufficient explanation it is misleading. What were the reasons to vote for suboptimal or even non-functioning technology? It is obvious to interpret HERMES as a political compromise with France and COLUMBUS as a political game with the U.S.. But games could also be played with functioning technologies. 15 And an important point - who is responsible for the irreversible social consequences of the decision for manned space flight? The German Space Agency DARA, brought into being by 'levers' such as HERMES, will persist even when HERMES is only a subject for techno-historians, just as NASA survived (even) when its original mission to bring a man to the moon had been completed. DARA as well as the new industrial aerospace leader DAIMLER-BENZ will generate their own social dynamics and will create ever new futuristic space flight projects (as NASA did). The failure of HERMES or, to take an example from the history of German space flight, the failure of the EUROPA-rocket in the 1960s did not deconstruct the social network of space flight and its social dynamics. Whether the technologies which helped to construct a social network, prove to be successful or not obviously doesn't affect the dynamics of the network. It is social autodynamics rather than technical dynamics which push the development of ever new space projects.

\section{The social construction of technological dynamics}

In order to understand the German decision to support the ESA programme, it is necessary to reconstruct the genesis of this decision. My starting point, which of course is artifical, since every historical event has predecessors and causes of its own, is the year 1983.This year marks a deep crisis in the German aerospace industry. After overproportional increases in the turnover rate in the late $1970 \mathrm{~s}$ the rates became small or even negative in the early 1980 s. 16 The typical life cycle curve of big technologies 17 can be regarded as an important factor in this cyclic industrial development.

In the FR Germany big programmes such as the combat aircraft TORNADO or the space laboratory SPACELAB were reaching the end of the production phase, and, seen from the viewpoint of the user of these systems, there was only little need for launching the next big programme at the beginning of the utilization phase of the previous one. But for the aerospace industry the follow-on problem was a real pressure. The same applies in the case of the big science laboratory DFVLR: The large R\&D programmes of the 1970 s were soon to be terminated; the ARIANE programme was to end in 1986, the spacelab programme in 1983.18

In this situation where the German aerospace industry and the big science laboratory were looking for follow-on projects, the American President Reagan announced his SDI-programme and one year later (1984) raised the project of an international space station. Both projects defined space as the front where technological superiority and national strength could be demonstrated. Both programmes offered opportunities for the cooperation of international partners, but the restriction of the fields of cooperation and the subordination under U.S. control indicate that both SDI and the space station can be interpreted as measures within the global high-tech race, primarily aimed at Japan and Western Europe and not at the Soviet Union. ${ }^{19}$ The American initiatives served as a support for the German space lobby who could now better argue that space flight was a main factor in international competition. The first German space programme released after SDI was a memorandum written by the German Association of the Aerospace Industry (BDLI), published in 1984. It is interesting to see that this memorandum not only calls for large new programmes (which is the duty of the aerospace lobby), but also tries to translate the demands of the industry into political terms. The BDLI argues that German space politics should be nationalized (i.e. the amount of the contribution to European programmes should be reduced) and the German aerospace market should be protected against foreign competitors. It submitted this concern with reference to the "political independence" (BDLI 1984: 72) which e.g. new data relay satellites give to the nations. The proposal of a "national military communication satellite system" (p.49) also indicates that in the age of SDI the space lobby could argue with reference not only to the industrial policy impacts of defence programmes (cf.p.46) but also to the specific military utility value of space systems - an argument which was a novelty in the German space discourse, but which again could be applied as a lever to convince politicans of the political value of space flight. Cooperation projects with the U.S. and France, i.e. COLUMBUS, ARIANE and HERMES, are assessed of low interest to Germany, while a European space station and national satellites are at the centre of the BDLI proposals. 
"European autonomy" and "German system leadership" became prominent terms in the programmes of the space industry lobby, indicating the political character of the argumentation. The Research Centre DFVLR also began to argue in this manner when it in turn released a voluminous "space flight strategy study" in 1984, which had been written by order of the Research Ministry. The arguments used to substantiate the projects listed by the DFVLR are much more sound and cautious than in the case of the BDLI, but the criteria for evaluation of the different scenarios discussed by the authors are purely political, namely European "autonomy" (DFVLR 1984:96) and "German leadership" (p.XIV) in the European space programme. It is not surprising that the scenario selected by using these arguments is judged to be the best way because of its political potential (p.XIII) and its flexibility for future modifications. Besides, this scenario puts emphasis on German space systems; the French proposal HERMES is not part of it.

In order to understand the new quality of the 1984 proposals, they must be compared with the previous memorandum, released in 1981 by the DFVLR together with the three major aerospace firms in Germany (Dornier, MBB, ERNO). Although military and political applications of space flight are also mentioned, the emphasis of the argumentation is on the innovation potential of space flight and especially of communication satellites (DFVLR 1981:2,7,11). Manned space flight only plays a subordinated role. In 1984 the new political context, produced by Reagan's initiatives one the hand, the new conservative government in the FR Germany on the other 20 , made possible new forms of political legitimation of space flight, and enabled a call to be made for programmes of new orders of magnitude.

The German government had no clear position. In a cabinet decision on January 16, 1985 it opted "for European independence and transatlantic cooperation" 21 and continued its traditional double strategy by voting for COLUMBUS and ARIANE. The French proposals for strengthening European cooperation in space, be it civilian or military, were sharply rejected:

"With the realisation of both these projects (COLUMBUS and ARIANE, J.W.) the

options of the German government, to embark on civilian (!?) projects of a similar size, are exhausted under the given circumstances." 22

This strategy of combining European with transatlantic cooperation in space flight, which had marked the German "Sonderweg" in space politics since 1962, had different implications for the discourse about space flight in the mid-eighties:

i) It showed that German government was willing to launch large new space projects and to commit itself to the novel political justification of space flight without regard to the use of space flight in terms of R\&D politics. Research Minister Riesenhuber clearly stated that he was not really willing to join those projects because he couldn't see any R\&D justification. He preferred to continue unmanned space research aimed at constructing a much smaller station than $\mathrm{CO}$ LUMBUS.

ii) At the same time the government's resolution really indicated a non-decision policy. In a situation where the U.S. had defined space as the place for a symbolic competition between the world's economic superpowers, a dual strategy above all was not sufficient to satisfy the advocates of a new Europe. Further it was illogical, seen from the viewpoint of space lobbyists, to rely on the good-will of the U.S. although European launching systems and space station elements were already available or under construction. The ESA decision of January 31, 1985 to accept the invitation to join the space station project expresses this mistrust, as to whether cooperation on the space station project could ever be realized "without discrimination" 23 against Europe.

The government's and the ESA decision of January 1985 thus indicate that outlines of a new space arena were fixed, but there still remained room for negotiation. The different partners were prepared to play the game, and a pre-selection of potential argumentative connections had been made: a justification of space projects by means of their scientific value, for example, was now socially much less valuable than a political justification, because it could not provide politicians with strong political arguments. Besides, such a justification was not acceptable to industry, which needed large long-time programmes for their own survival. A small number of scientific satellites could not serve this purpose, but a large number of military satellites or a complex configuration of manned systems could.

The years from 1985 to 1987 can thus interpreted as a period of intensive "Kontextsteuerung" (Wilke) (contextual control), in which the different actors in the space arena strengthened the network by generating arguments which fitted the strategies of their partners and helped to promote their positions. The remarkable result of this process is the fact that ESA revisited its "Long Term Space Plan 1985 - 1995" 24 only two and a half years after it was passed in January 1985 and voted in November 1987 for the new long term programme mentioned above.The main difference between the two programmes is the emphasis the 1987 plan puts on autonomous European space flight. This was symbolized by HERMES which now became another central element of the programme. Different factors played an important role in this process of negotiation. Some were external, such as the CHALLENGER accident. Others came from the European stage, where especially France was busily working to get the HERMES project launched. But most important is the way actors in the national space arena worked with the options available in the context, and how they shaped their strategies according to changing situations.

In these discourses scientific or even technological or economic considerations played only a minor role. It is hardly understandable that Europe should, according to the decision taken in 1987 , re-invent the space shuttle only to have a means of decoupling from the space station they 
just have coupled to with COLUMBUS. This programme is not only immanently illogical, its economic effiency and its scientific value are also questionable. Its technically suboptimal shape can only be understood as a result of negotiations between different interest groups and as a political compromise between different partners.

The crude logic of the space programme was formulated by an expert group of a German policy research institute (DGAP) which united representatives of all interest groups in the space arena. It served as an intermediate organisation which linked the different positions and harmonized the interests and the arguments of the space lobby. In this way it strengthened the positions of its members: a space scientist could now argue, faced with opposite views in his scientific community, that his view was part of a network and that space science had to join the unavoidable trend. The core-argument which held this network together and which thus served as a social link was expressed in a memorandum of this expert group released in 1986. It states that West Germany has to become the "shaping power of a West European space power" (DGAP 1986:42). In a democratic society such as the FR Germany the social acceptability of a large space programme and its budgetary consequences, according to the memorandum, can only be achieved by a national consensus, which in turn could be stimulated by the "higher political symbol-effect" (p.38) of manned space flight.

The intermediate function of the DGAP is thus evident. Firstly it served as a hybrid community between different social groups. Secondly it made available an argumentative figure (manned space flight as a means of national politics to conquer the world) that could not only convince the public but could also be retranslated into the subjective images of the different interest groups. For the group of the 'Europeans' within politics space flight now served as a symbolic means of European integration. For space scientists it helped to define new research frontiers, which had to be promoted by R\&D-programmes. And for the aerospace industry manned space flight was the way out of the dilemma of the cyclic development of big technologies, since ESA plans covered a period of at least 10 to 15 years and a long-term committment of the government to space flight could be expected. It is understandable that this space network had a strong momentum and could not even be stopped by well-founded arguments against manned space flight. As the network included social actors, it also excluded others.

\section{Technology discourses as a 'lever' for social innovation}

The previous chapter has demonstrated that a technology programme may be the integrating element of a social network and the trigger of social dynamics. Now an attempt will be made to integrate this empirical evidence into a sociological model. This model must answer the question why technology can serve as an intermediate factor in social interactions.

Since there are as many notions of technology as there are sociologies of technology, I shall try to answer the question from another starting point, i.e. the analysis of the interactions of social systems. An important theoretical assumption in my considerations is the premise that no separate social system 'technology'exists, but society can, according to Luhmann, be differentiated in social sub-systems such as science, economy and politics (to mention only those subsystems which play a role in space politics). ${ }^{25} \mathrm{~A}$ second assumption, derived from different concepts of systems theory (Wilke, Krohn/Küppers) claims that in a functionally differentiated society which has no privileged position for a central control, actors can only control other coactors by "Kontextsteuerung" (contextual control), i.e. by incentives which can be accepted by the addressee, but which, however, can also be rejected. 26 The producer of a social offer (e.g. a new research programme) has no control over the behaviour of his addressees. If this sounds like an "anything goes"-game, systems theory makes an important theoretical point in resolving this arbitrarity of social interaction and/or non-interaction when it focusses on the systemic conditions of "Anschlußfähigkeit" (social linkability). The social logic of the science system is the production of knowledge, the logic of the economic system is to deal with goods and money, and the political system operates with the logic of power. These three systemic mechanisms are not comparable or interchangeable: Expensive research need not be true just as true knowledge need not be profitable. Luhmann deserves the credit for calling the sociologists' attention to the fact that social systems cannot communicate with each other on the level of their systemic code. Intersystemic communication in his view only takes place in a few cases where an event has a functional meaning in two systems. Luhmann doesn't discuss the question of which events are likely to be communicated in different social systems and what social actors could do to increase the likelihood of intersystemic communication. These questions are outside the range of Luhmann's interests.

My claim now is that there are some social phenomena which possess a general "Anschlußfähigkeit" in the sense that different social systems can communicate them because they fit into the social logic of the respective systems. Technology seems to be an intersystemic structure of this kind: it can be handled by the science system, since technological work is research in the sense of knowledge production. It cannot be distinguished from other research by the type of action required and the systemic code separating research from non-research. 27 From the perspective of the economic system, technology is a factor which affects production success. And the political system, finally, can deal with technology as a means of generating political power and/or legitimacy e.g. in the case of health, transport, communication or war technologies.

This view implies a constructivistic perspective insofar as each social system interprets a concrete project, e.g. the space station, by its own systemic view. At the same time my approach tries to circumvent the trap Pinch and Bijker never found their way out of, when they had to introduce into their model the fact that despite different interpretations the artefact really exists. In my model the artefact plays a minor role, maybe because discourses in the specific case of space flight are mostly conducted a long time before the technologies are really built. As 
mentioned in a previous chapter, artefacts do not disturb the discourse. What is communicated between different social groups are utopian ideas or visions of technology which may be interpreted in quite different ways with reference to the specific view of each system involved. Whether a consensus can be achieved that various partners are talking about the 'same' object is not a question of theory but of history.

At the same time, however, it is evident that strategic actors do not wait for intersystemic coupling to happen by chance (which is, as Luhmann says, rather unlikely), but actively try to construct chances. As Hughes showed very convincingly, innovative actors systematically integrate different perspectives (technical, economic, political) into their considerations and their strategies. 28 They do not simply react to their social context, but try to shape this context in a way that serves their interests. Krohn/Küppers have integrated this aspect of strategic action and strategic networking into their model 'self-organization of science'. Technology could be, even if not explicitely mentioned by Krohn/Küppers, one of the feed-back loops by which social actors influence their context on the one hand, and import resources as levers for social innovations on the other. The latter is a significant aspect: intersystemic communication is not an end in itself, but a selfish purpose. Actors who mobilize other actors, construct intersystemic networks and mutually exchange resources do this because of the social benefits they can attain in this way. A simple example may illustrate this: a scientist who can make use of a novel research programme has competitive advantages compared with his colleagues. However, he can draw, a maximum profit from such a constellation, if the initiative for the research programme has been his idea and if he has been able to form the shape of this programme according to his own purposes. This again is only possible if he can offer something to politics that has a specific political value, e.g. a ballistic missile defence, a cure-all for AIDS or the technology for everlasting wealth (superconduction?). The example shows very convincingly that technology is a well-suited means of translation between different social logics. Because of this feedback mechanism in practice we will mostly observe interactive processes of mutual control, in which the translation of specific interests into the 'language' of other actors is the major task of strategic players. 29

\section{Conclusion}

The sociological concept of technology discourses as a lever for social innovations, outlined very briefly 30 , will hopefully contribute to a better understanding of the dynamics of big technology programs. Firstly, the model points to the fact that large scale technologies need equally large scale social support. To construct this social basis techno-visions are invented which serve as links between different actor groups and their individual interests. Since these visions must be acceptable in different social systems, translations into the different 'languages' of the social systems must be made. If the translations fit to each other, the network will work and gain its own dynamics, if not, it will fail. Secondly the model draws attention to the problem of retranslation: For example a research group involved in hypersonic research that can only ensure the continuation of its work by integration into a programme of manned space flight is then forced to construct manned systems (e.g. HERMES), even if this purpose is not considered to be valuable by the scientific community. In this way, the network may develop autodynamics which produce effects the individual actors did not aim at. Thirdly the model focusses on the relation between technical and social dynamics, as it shows that technical innovations, or more specifically discourses about such innovations, are a means for the achievement of social innovations. As soon as these social innovations are accomplished, they may 'forget' their history: whether HERMES will fly or not will probably not affect the institutional innovations generated by the 'lever' HERMES. Artefacts need not interfere with discourses, and discourses need not necessarily lead to functioning technologies. 'Negotiation about technology' is a strategic game with social implications which cannot be reduced to technical impacts.

Notes:

(1) ESA/C (87)3, Paris, 10 june 1987 (mimeo)

(2) Memorandum 1987: 39,66; Weyer 1987

3) Frankfurter Allgemeine Zeitung (FAZ), 7.11.1989

(4) cf. Memorandum 1987: 65 (Prozentuierung von Reihe 9 und 7)

(5) Out of the large number of references only a recent example will be quoted here: it is reported that experiments on crystal growth on board of the U.S. shuttle have been unexpectedly successful. But at the same time the presence of the astronauts is criticized by the experimenters as a serious obstruction. (FAZ 29.11.1989, p.N1)

(6) cf. DGAP 1986, Schreiber 1986, Genscher 1987, from a critical perspective: Schierholz 1987

(7) This strategy only works if the mission succeeds - a high-risk option for politics. (cf. Luft- und Raumfahrt 2/1988:28, where it is reported that it was discussed whether to delay the launch of a U.S. shuttle because of the presidental elections.)

(9) which do not really exist on board of the space station

(10) cf. Beratender Ausschuß 1987; Heraeus, in: Der Spiegel 34/1987, 36pp.

(11) Luft- und Raumfahrt 2/1988:38; MBB-Aktuell

(12) It is typical that parallel with the decline of the station new futuristic space projects are submitted in order to recover political support for NASA.

(13) In the definition phase of space projects the technical design must be "frozen" (Orientierungsrahmen 1987:9) in order to secure technical coherence of the product. In the case of large-scale and long-term projects his may lead to the consequence that computer technologies are applied in space which our children would no longe accept for their computer games.

(14) FAZ 31.10 .1989

(15) It may be argued, but will probably never be proved that the U.S. had defined space as the new frontier for the purpose of orienting the Europeans towards economically foolish projects.

(16) cf. Hornschild/ Neckermann 1988:2

(17) cf. Hornschild/Neckermann 1988:50; becomes especially apparent if two curves are superimposed.

(18) DFVLR 1984:1

19) cf. Bluth 1986 for the large number of studies on the European reaction to SDI.

(20) After the 'Wende' (change of government) in Bonn in 1982 the 1970 s were re-interpreted as a time of depression ("Talsohle"), followed by an impetus ("Aufschwung") after the installation of the conservative government. (quotes from Haunschild, in: DFVLR-Nachrichten 50/1987:17)

(21) quoted from BMFT (ed.), Übereinkommen über die Internationale Raumstation und das Programm COLUMBUS, Dokumentation (22. Juli 1988), p.86, emphasis added

(22) source seen fn. 21

(23) ESA-Rat, Entschließung über die Beteiligung am Raumstationsprogramm (angenommen am 31. Januar (Final), Paris, 4. Februar 1985, source see fn 21, p.90

(24) ESA/C(84)46, rev.1, Paris, 21. November 1984 
(25) cf. Luhmann 1987

(26) Krohn/Küppers 1989; Wilke 1984

(27) cf. Krohn/Rammert 198

(28) cf. Hughes 1987

(29) This concept differs from the original notion of "Kontextsteuerung" generated by Wilke, because he usually concentrates on the process of uni-directional action or argues from the point of view of an enlightened societal metarationality.

(30) A more detailed presentation of the model can be found in Weyer 1989.

\section{Bibliography:}

Anhörung: Deutscher Bundestag, 1985: Ausschuß für Forschung und Technologie, Stenographisches Protokoll der 46. Sitzung des Ausschusses am 11./12.11.1985, öffentliche Anhörung "Weltraumforschung Weltraumtechnik" (verv. Ms.)

BDLI - Bundesverband der Deutschen Luftfahrt-, Raumfahrt- und Ausrüstungsindustrie e.V., 1984: BDLIMemorandum zur Zukunft der Raumfahrt in der Bundesrepublik, Bonn (verv. Ms.)

Beratender Ausschuß der Industriephysiker, 1987: Memorandum zur Materialforschung mit bemannter Raumfahrt. In: Physikalische Blätter 43: 375-376

Bluth, C., 1986: SDI: The challenge to West Germany, in: International Affairs 1986: 247-264

DFVLR, 1984: Deutsche Forschungs- und Versuchsanstalt für Luft- und Raumfahrt, Strategiestudie Raumfahrt, o.O. (Köln)

DFVLR/Dornier/MBB/ERNO, 1981: Memorandum zur Zukunft der Raumfahrt in Deutschland, Bonn, Juni 1981 Forschungsinstitut der Deutschen Gesellschaft für Auswärtige Politik, 1986: Deutsche Weltraumpolitik an der Jahrhundertschwelle, Analyse und Vorschläge für die Zukunft (Vorsitz: Karl Kaiser), Bonn

Genscher, H.-D., 1987: Kontinuität und Wandel. Moderne Außenpolitik in der Perspektive 2000. In: Ders. (Hg.),

Hornschild, K./Neckermann, G., 1988: Die deutsche Luft- und Raumfahrtindustrie. Stand und Perspektiven, Frankfurt/New York: Campus

Hughes, T.P., 1987: The Evolution of Large Technological System. In: W.E.Bijker, T.P. Hughes, T.J. Pinch (Eds.), The Social Construction of Technological Systems. New Directions in the Sociology and History of Technology, Cambridge (Mass.)/ London: MIT Press, 51-82

Krohn, W./Küppers, G., 1989: Die Selbstorganisation der Wissenschaft, Frankfurt: Suhrkamp

Krohn, W./Kuppes, G., 1989. Die Selbstorganisation der Wissenschant, F rankurt. Suhrkamp Soziologie und gesellschaftliche Entwicklung. Verhandlungen des 22. Deutschen Soziologentages in Dortmund 1984, Hg.: B. Lutz, Frankfurt/M., New York: Campus, 411-433

Krupp, H.Weyer J. 1988, Die gesellschaftliche Konstruktion einer neuen Technik. Legitimationsstrategie Dur., Durchsetzung der bemants und 1249-1262

Luhmann, N., 1987: Wissenschaft als soziales System (verv. Ms.)

Memorandum, 1987: Kritik der Bonner Weltraumpolitik. Orientierungsrahmen Hochtechnologie Raumfahrt 1987: Gesamtüberblick und Empfehlungen. Hg.: Deutsche Forschungs- und Versuchsanstalt für Luft und Raumfahrt.

Schierholz, H., 1987: Die Beherrschung des Raumes. Die neo-imperialen Ambitionen bundesdeutscher Weltraumpolitik. In: Forum Wissenschaft 3/87, 23-25

Schreiber, W., 1986: Die Bedeutung der Erforschung und Nutzung des Weltraums für die militärische Sicherheit. In: Europa-Archiv 21/1986: 629ff.

Weyer, J., 1987: Subventionsruinen im erdnahen Orbit. Fiskalische Konsequenzen der Bonner Weltraumpolitik. In: Forum Wissenschaft 3/87: 15-19

Weyer, J., 1988a: Bemannte Raumfahrt: Taktische Spiele im All. In: Die ZEIT 22.4.1988, 36-37

Weyer, J., 1988b: European Star Wars. The Emergence of Space Technology through the Interaction of Military and Civilian Interest Groups, in: E. Mendelsohn/MR Smith/P. Weingart (Eds), Science, Technology and the Military (Sociology of the Sciences. A Yearbook, VolXI), Dordrecht/Boston/Lancaster/Tokyo: Kluwer, 243-288

Weyer, J. 1989: "Reden über Technik" als Strategie sozialer Innovation. Zur Genese und Dynamik von Technik am Beispiel der Raumfahrt in der Bundesrepublik. In: M. Glagow/H. Wiesenthal/H. Wilke (Hg) Systemische Steuerung und partikulare Handlungsstrategien, Pfaffenweiler: Centaurus, 81-114

Wilke, H., 1984: Gesellschaftssteuerung zwischen Korporatismus und Subsidiarität, Bielefeld: AJZ Verlag, 29- 